\title{
Environmental Mercury Contamination Around Chlor-Alkali Plant
}

\section{Lodenius, M.}

Springer-Verlag New York Inc.

1984

Lodenius, M. and Tulisalo, E. 1984. Environmental Mercury Contamination Around

Chlor-Alkali Plant. Bulletin of Environmental Contamination and Toxicology 32: 439-444.

http://hdl.handle.net/1975/201

Downloaded from Helda, University of Helsinki institutional repository.

This is an electronic reprint of the original article.

This reprint may differ from the original in pagination and typographic detail.

Please cite the original version. 


\title{
Environmental Mercury Contamination Around a Chlor-Alkali Plant
}

\author{
Martin Lodenius and Esa Tulisalo \\ Department of Environmental Science, University of Helsinki, \\ SF-00710 Helsinki 71, Finland
}

The chlor-alkali industry is one of the most important emitters of mercury. This metal is effectively spread from chlor-alkali plants into the atmosphere and it has been reported that only a few percent of the mercury emissions are deposited locally the major part spreading over very large areas (Jernelöv \& Wallin 1973, Lockeretz 1974, Wallin 1976, Högström et al. 1979). The purpose of this investigation was to study the spreading of mercury up to $100 \mathrm{~km}$ from a chlor-alkali plant using three different biological indicators.

\section{MATERIAL AND METHODS}

The chlor-alkali plant is situated at the shore of Kokemäenjoki river in southwestern Finland. The mercury emission into the air was approximately $400 \mathrm{~kg}$ in 1981 and there are no other important mercury emitters in this area. Southerly winds prevail (Fig. 1 ). The mercury pollution of terrestrial and aquatic vegetation, lichens and fungi has been studied earlier (Lodenius 1980, 1981ab; Lodenius \& Herranen 1981). A rural, unpolluted area $225 \mathrm{~km}$ east of the factory was used as a background area.

Mosses and lichens have been widely used as indicators of air-borne metal pollution. The moss-bag technique (Goodman et al. 1974, Mäkinen 1977) is especially suitable for monitoring dry deposition (Clough 1975), which is the main fallout process for mercury (Högström et al. 1979). However, the exact relationship between the actual deposition and the moss-bag value is not known.

The moss-bags were made of Sphagnum fuscum, S. riparium and $S$. balticum collected from unpolluted sites. The moss material was rinsed with deionized water, placed in polyamide nets and hung in trees at a height of 3-5 m (cf. Mäkinen 1977). Some of the moss material was rinsed with $0.5 \% \mathrm{HNO}_{3}$ or $5 \%$ EDTA. However, the mercury contents of rinsed material did not differ from those obtained by untreated moss-bags and consequently rinsed and un$r$ insed data were combined. The mean dry weight of moss covering $1 \mathrm{dm}^{2}$ was determined to be $3.2 \mathrm{~g}$. Moss-bags were placed along a transect $0-100 \mathrm{~km}$ north of the factory and along a 0-20 km transect 
Fig. 1. The reverse wind rose

for the study periods in 1982

and 1983 constructed on the

basis of values from Tampere

airport $60 \mathrm{~km} \mathrm{NE}$ of the factory.

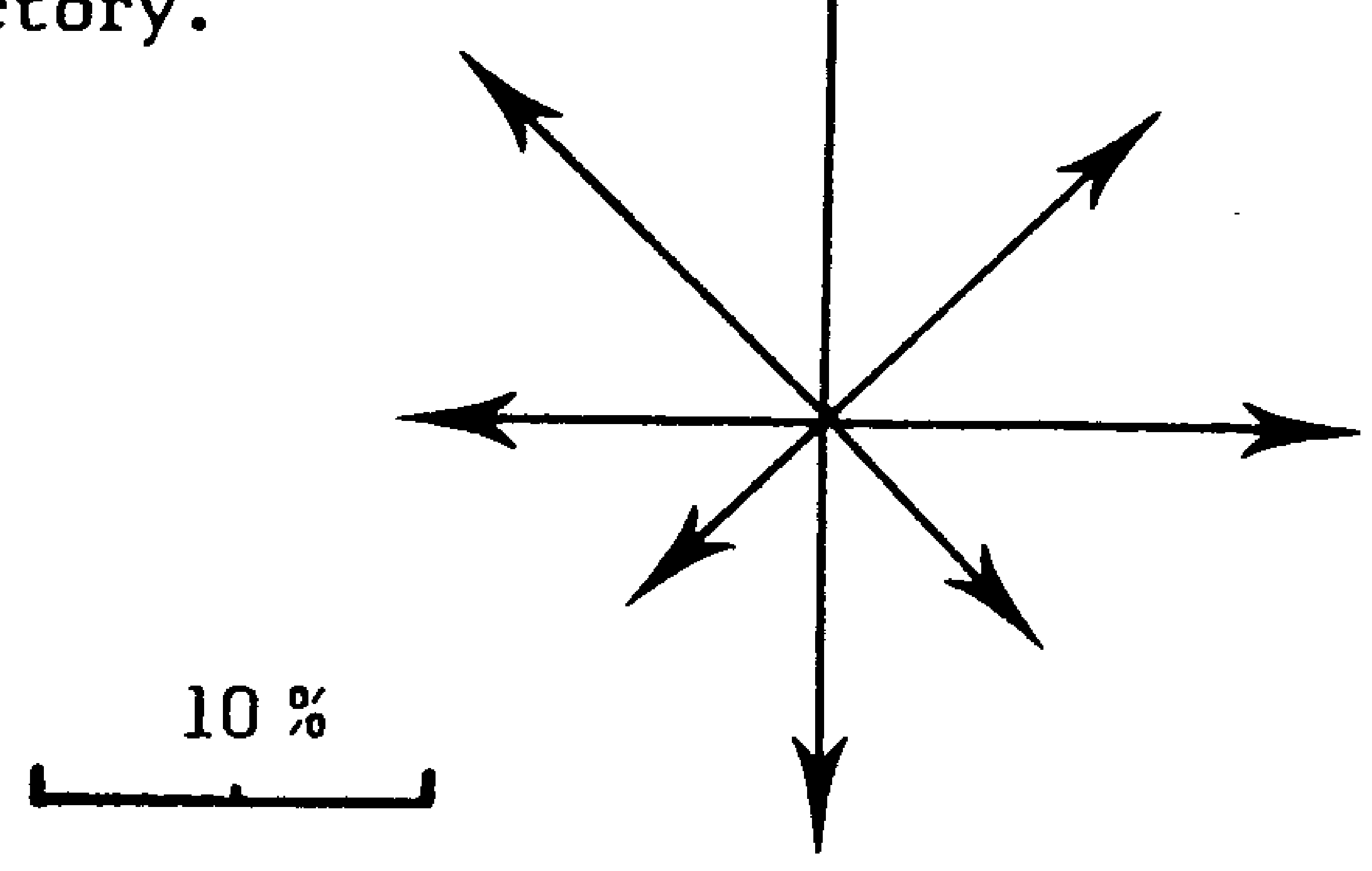

northeast of the factory at 34 sites for the period June - September 1982 (108 days). The experiment was repeated in February - May 1983 (92 days) at the northeast transect.

In September 1982 tivo-year old shoots of feather moss, Pleurozium schreberi, were collected from the two transects from 28 sites (no Pleurozium was found near the factory). Samples of the epiphytic lichen Hypogymnia physodes were collected both in September 1982 and February 1983.

\section{RESUL TS AND DISCUSSION}

The mercury accumulation in moss-bags and the concentrations in mosses and lichens were significantly higher near the chlor-alkali plant than 20-100 km distant or in the background area (Table 1). The moss-bag and moss values were also higher $20-100 \mathrm{~km}$ from the plant than in the background area. The mean mercury content of Hypogymnia was slightly lower than in the background area, but higher than the mean background value for the whole of Finland (Lodenius 1981b). The variation in mercury values was greater at sites $20-100 \mathrm{~km}$ than in the background area obviously because of the greater heterogeneity in the sampling sites along this very long transect.

The moss-bag and lichen values did not differ significantly between the two study periods indicating that no substantial differences in the mercury deposition occur between summer and winter. Nor did 


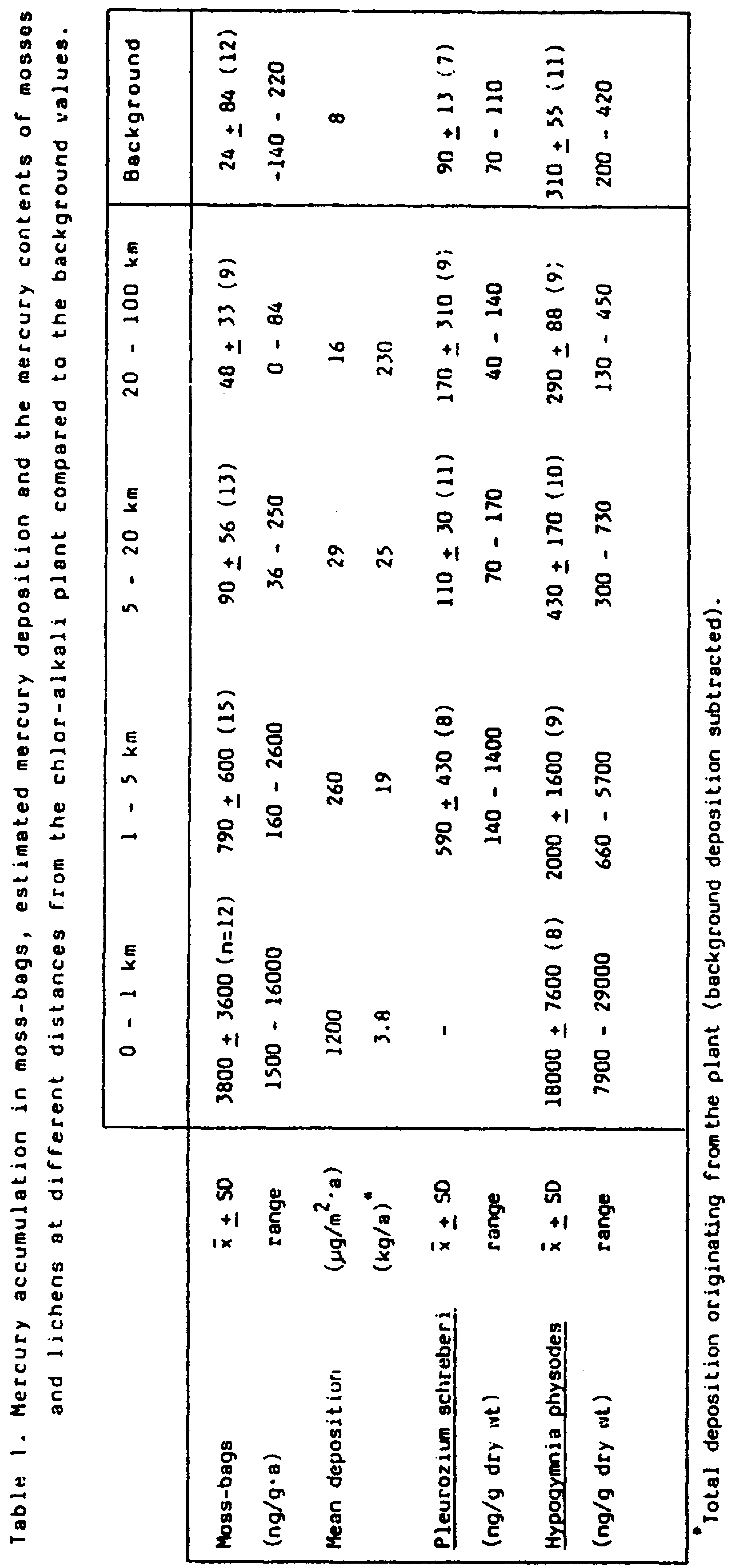



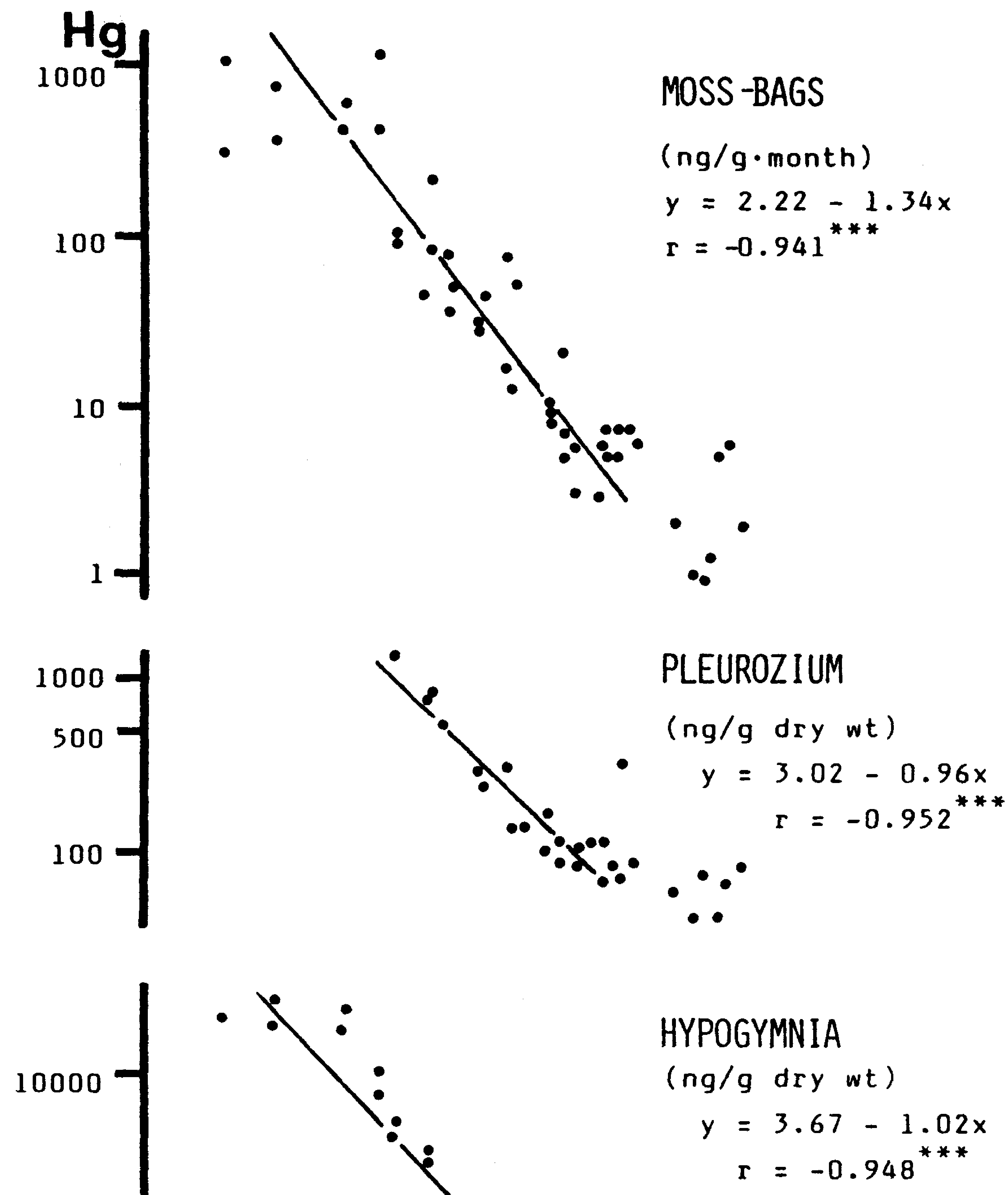

Fig. 2. The mercury accumulation in moss-bags and the mercury contents of Pleurozium schreberi and Hypogymnia physodes at different distances from the chlor-alkali plant. The correlations are calculated from data $0-20 \mathrm{~km}$. 
the values differ between the two transects and all results are included in Table 1 and Fig. 2 .

The mercury values decreased exponentially with increasing distance from the plant as observed earlier (e.g. Wallin 1976, Lodenius \& Herranen 1981). At distances of $0-20 \mathrm{~km}$ the negative correlations between the logarithmic values of distance and mercury contents were significant for all three indicators ( $F$ ig. 2). Consequently all these materials may successfully be used as bio-indicators of air-borne mercury pollution.

On the basis of the specific weight of the moss used for moss-bags a rough estimation of the mercury deposition around the chloralkali plant was made (Table l). This implies that only 6\% of the emission is deposited $0-5 \mathrm{~km}$ from the factory, which is in good agreement with the results from six Swedish chlor-alkali plants (Wallin 1976). Almost 60\% of the emitted mercury is deposited at distances of 20-100 km. Bull et al. (1977) estimated from mossbags a slightly higher annual mercury deposition near a chloralkali plant: $2300 \mathrm{\mu g} \mathrm{Hg} / \mathrm{m}^{2}$ near the factory $(<0.5 \mathrm{~km})$ compared to $130 \mu \mathrm{Hg} / \mathrm{m}^{2}$ further distant $(10-30 \mathrm{~km})$.

Acknowledgements: We are indebted to $V$. Hynninen for technical assistance and the Academy of Finland for financial support.

\section{REFERENCES}

Bull KR, Roberts RD, Inskip MJ, Goodman GT (1977) Mercury concentrations in soil, grass, earthworms and small mammals near an industrial emission source. Environ Pollut 12:135-140

Clough WS (1975) The deposition of particles on moss and grass surfaces. Atmos Environ 9:1113-1119

Goodman GT, Smith S, Parry GDR, Inskip MJ (1974) The use of mossbags as deposition gauges for air-borne metals. Proc Conf Nat Soc. Clean Air 16 pp.

Högström U, Enger L, Svedung I (1979) A study of atmospheric mercury dispersion. Atmos Environ 13:465-476

Jernelöv A, Wallin T (1963) Air-borne mercury fall-out on snow around five Swedish chlor-alkali plants. Atmos Environ 7:209-214

Lockeretz $W$ (1974) Deposition of airborne mercury near point sources. Water Air Soil Pollut 3:179-193

Lodenius M (1981) Observations on mercury fall-out in terrestrial vegetation around three $F$ innish chlor-alkali works. Luonnon Tutkija 85:174-175

Lodenius M (1980) Aquatic plants and littoral sediments as indicators of mercury pollution in some areas in Finland. Ann Bot Fenn 17:336-340

Lodenius M (1981) Regional distribution of mercury in Hypogymnia physodes in Finland. Ambio 10:183-184

Lodenius M, Herranen M (1981) Influence of a chlor-alkali plant on the mercury contents of fungi. Chemosphere 10:313-318 
Mäkinen A (1977) Moss- and peat-bags in air pollution monitoring. Suo $28: 79-88$

Wallin T (1976) Deposition of airborne mercury from six Swedish chlor-alkali plants surveyed by moss analysis. Environ Pollut $10: 101-114$

Received August 26, 1983; Accepted September 16, 1983. 